Philip Wesley Routon' / Reanna Berry ${ }^{2}$

\title{
Accounting Education, Economics Education, and Opinions on Taxing the Wealthy
}

\author{
${ }^{1}$ Department of Economics, School of Business, Georgia Cwinnett College, 1000 University Center Lane, Lawrenceville, GA \\ 30043, USA, E-mail: prouton@ggc.edu. \\ ${ }^{2}$ Instructor of Accounting, School of Business, Georgia Cwinnett College, 1000 University Center Lane, Lawrenceville, CA \\ 30043, USA, E-mail: rberry3@ggc.edu.
}

\begin{abstract}
:
Determining the appropriate tax rate for the wealthiest citizens is a topic of much debate in the political, social, and economic spheres. Opinions vary considerably. Arguably, accounting and economics are the two collegiate majors of study where the theory of taxation and tax law are most often discussed. Due to higher focus on the topic, students graduating with accounting or economics degrees may have differing views of taxation compared to other graduates. An understanding of these differences has potential implications for policy, pedagogy, and the professions of accounting and economics. Using longitudinal survey data on students from 619 American colleges and universities, the differences in opinions on taxing the wealthy for accounting and economics majors, compared to others, are examined. Accounting and economics majors are found to both begin and end their collegiate tenure with statistically different tax opinions than other majors. Evidence is uncovered that, on average, both programs of study make students somewhat less likely to favor a policy which would increase the taxes paid by the wealthy. Within accounting education, opinion change is more prominent for students from high-earning families, males, non-minorities, and at right-leaning institutions, while the estimated impact of economics education is relatively universal.
\end{abstract}

Keywords: taxing the wealthy, tax opinions, accounting education, economics education, student opinions

JEL classification: H21, A22, I23

DOI: $10.1515 /$ ael-2017-0041

\section{Introduction}

Accounting has been called the 7th most popular college major in the U.S. (Stockwell, 2014; Tetzlaff, 2016) and economics consistently ranks in lists of the top five ' best' college majors e.g. (Franek, 2017). The latter is the broad study of human action as it particularly relates to choices and the utilization of scarce resources, while the former focuses on direct measurement, processing, and communication of financial information about economic entities (Needles \& Powers, 2013). Specialized coursework on taxation is completed by individuals who major in accounting or economics in college, while other majors do not often engage in focused study of taxation (Roberts, Hite \& Bradley, 1994). Other collegiate fields, such as political science, sociology, and any field where economic inequality is a topic of interest, do discuss taxation though typically not to the degree of the fields of accounting and economics. Accounting taxation coursework often emphasizes policy and calculation, while economics coursework prioritizes the theory and evidence surrounding the purpose and effects of taxation at both the micro (individual) and macro (economy-wide) levels. Therefore, accounting and economics majors gain relatively more of the knowledge necessary to analyze tax policy due to their education (Roberts et al., 1994; 2010; 2016).

Such knowledge potentially enables accounting and economics majors to influence society. For example, since U.S. tax policy is in a state of overwhelming complexity (Smith, 2002; Dean, 2005; Bobek, Chen, Hageman \& Tian, 2016; Advocate, 2016), individuals with more specialized knowledge are often asked for their opinions on tax policy. These opinions may be sought by policymakers or the voters who elect them. Beyond providing opinions, accountants, in particular, have been thought to form socio-economic realities because they apply the decisions of policymakers through the reporting of financial information (Biondi \& Suzuki, 2007). Therefore, understanding the influence of studying accounting and economics on an individual' s opinions of taxation is of importance.

Philip Wesley Routon is the corresponding author

(c) 2018 Walter de Gruyter $\mathrm{GmbH}$, Berlin/Boston.

This content is free. 
For three related reasons, the analysis here focuses on taxation of the wealthy. First, the marginal tax rates of the wealthiest $1 \%$ of taxpayers have undergone the most observable fluctuations over time, from $28 \%$ in 1988 to $39.6 \%$ in 2017 (Service, 2017; Piketty \& Saez, 2007). Second, wealthy tax payers often represent complex tax situations because these payers commonly incur other income-based taxes such as capital gains tax, dividend tax, and alternative minimum tax in addition to marginal taxes (Piketty \& Saez, 2007; Shevlin, 2007; Schreiber, 2015; Moore, Pack \& Sabelhaus, 2016). Third, students have been shown to be the most misinformed about the amount of taxes paid by the top $20 \%$ of taxpayers compared to other taxpayers (Settlage, Settlage \& Wollscheid, 2015). In short, taxes paid by the wealthy are the most variable, complex, and misapprehended. Taxation of the wealthy is also a well researched academic topic, with one central theme being that it is often a difficult task for governments and societies (Tanzi, 2014; Zucman, 2015).

The following questions are examined. What are the taxation opinions of economics and accounting students at college matriculation, graduation, and how much change is taking place? How do these opinions and changes therein compare to other groups of students? Controlling for relevant factors, what are the estimated average effects of accounting and economics education on the probability of opinion change and its direction? If such effects exist, do they differ across student and institutional characteristics?

This study relates to the existing research on the relationship between higher education and socioeconomic/political opinions. Others have largely focused on examination of students' broad political views e.g. (Scott \& Rothman, 1975), while the examination of taxation opinions provides insight into a specific politicaleconomic viewpoint of graduates. Such insight is valuable in the broader study of market stability (Biondi, 2016), though that context is not explicitly explored here. Additionally, evidence here expands the socioeconomic study of the field of accounting. Socio-economists often examine the societal impact of ' ubiquitous routines' of daily life, yet accounting has been largely omitted from this study (Biondi \& Suzuki, 2007). Arguably, paying taxes is one of the most ubiquitous routines of daily life, and this routine is heavily based in the field of accounting. Therefore, findings regarding the taxation opinions of accounting majors are relevant for future socio-economic analysis. Lastly, this analysis adds evidence to the debate surrounding the value of a college degree (e.g. Leonhardt, 2014; Selingo, 2015; Webber, 2016; Douglas-Gabriel, 2016), since, according to enlightenment theory, documenting changes in opinion of accounting and economics majors demonstrates that learning has occurred for these degree holders (Davis \& Robinson, 1991; Weakliem, 2002).

The sample used may be thought national as it consists of a large number of students from over 600 different American colleges and universities. Undergraduate accounting and economics majors are indeed found to have statistically different opinions than other students at both matriculation and graduation, regardless of whether one considers those who were always within one of these disciplines, those who changed majors into accounting or economics, or both. Interestingly, approximately 63\% of American college students are estimated to change their opinions on taxation of the wealthy during collegiate tenure. However, both accounting and economics majors are even more likely to do so. Further, holding constant matriculating opinions, political leanings and changes therein, student demographics, academic prowess, household and institutional characteristics, and other collegiate experiences does not diminish the statistical significance of the impact of accounting and economics education. Students in these disciplines more often change opinions, and on average become somewhat less likely to favor further taxation of the wealthy. For accounting students, opinion change is more prominent for students from high-earning families, males, non-minorities, and at right-leaning institutions, while the estimated change for economics majors is relatively universal. The following section presents a brief discussion regarding the influence of education on opinion, with a focus on accounting and economics.

\section{Education and opinion}

One influence on the formation of opinions is undoubtedly education. Formal education causes students to have a greater understanding of society as a whole and to subsequently form opinions based on this greater understanding, according to enlightenment theory, also called the enlightenment thesis (Davis \& Robinson, 1991; Weakliem, 2002). In particular, research has shown that a formal college or university education strongly influences the formation of opinions by students (Nasatir, 1968). However, this formation of opinions does not result in unanimity of opinion (Rose, 1963). Lack of unanimity indicates that the formed opinions may be the result of critical thinking rather than mimesis.

Researchers have suggested that the focus on quantitative analysis in accounting and economics education can sway student viewpoints (Glover, 2014; Malek, Hall \& Hodges, 2016). Accordingly, changes in opinion have been utilized to support the notion that economics education is associated with learning. Using a sample of students from a single institution, Riddle (1978) found that students generally held more conservative opinions after completing an introductory economics course. Subsequently, Hammock, Routon, and Walker (2016) used 
a larger sample of students from multiple colleges and universities and found that economics majors changed their opinions on a varied set of topics in directions that demonstrated an increased importance of personal freedoms. In each study, the researchers relied on a pedagogical analysis of the change in student opinion. Similar research on accounting education is relatively scarce.

Other researchers have utilized political analysis to examine the change in student opinion. Three complementary studies find slight shifts toward conservative political opinions following completion of a basic economics course (Scoot \& Rothman, 1975; Luker \& Proctor, 1981; Jackstadt, Brennan \& Thompson, 1985). Interestingly, the slight shift toward conservative opinions is based on an analysis of the instrument questions as a whole. Analysis of individual questions representative of specific topics sometimes revealed a shift toward a liberal opinion (Jackstadt et al., 1985). Therefore, economics courses do not make students universally conservative, so other influences on student opinion may exist beyond the knowledge and skills gained through formal education. Again, accounting education has been less studied in this regard.

Another influence on student opinion is likely perception, both individual and environmental. With regard to taxation, some scholars believe that perception supersedes political ideologies (Ubel, 2017). Empirical evidence supports the notion that as an individual' s perception of their socio-economic status increases the individual is more likely to disagree with income redistribution through taxation of the wealthy despite the individual' s actual income or education level (Brown-Iannuzzi, Lundberg, Kay, \& Payne, 2015). Further, researchers have noted an association between students attending affluent schools and adopting economically conservative views, but the researchers are clear that this association only partly explains why students adopt conservative views (Mendelberg, McCabe \& Thal, 2017). Thus, there are confounding factors to consider when estimating the impacts of educational programs on student viewpoints, inclusive of taxation opinions.

For not just students, but for the broader population, the issue of tax perceptions and beliefs has been largely debated among researchers with regard to changing opinions, ignorance, or misunderstanding. Kinsey, Grasmick, and Smith (1991) use the concept of framing from behavioral decision theory to demonstrate where opinions on equitable taxation may come from, finding that tax avoidance policies increase perceptions of unfairness in the tax system. Edlund (2003) uses taxpayer survey data to show that Americans, but not Swedes, report contradicting opinions on progressive taxation depending on how the question is posed. Bartels (2005) argues that much of the indifference of Americans to the Bush administration tax cuts (2001 and 2003) stemmed from general inability to connect public policy and economic inequality, as opposed to a lack of interest in inequality. Other work in this area includes that of Keene (1983) and Slemrod (2006). Formal education, such as that received in a collegiate accounting or economics program, can alter opinions, and is designed to correct ignorance and misunderstandings. Thus, for these multiple reasons, we expect to find evidence of opinion change that stems from these programs. The following section details the data used in this study and presents the results from a descriptive analysis.

\section{Tax opinions of accounting and economics students}

Data for this analysis come from the Higher Education Research Institute, which runs the Cooperative Institutional Research Program (CIRP) housed at The University of California - Los Angles. The CIRP administers several surveys. The Freshman Survey (TFS) and College Senior Survey (CSS) are incorporated here. The former is administered very near a student's matriculation, while the latter very near graduation, most often as entrance and exit surveys respectively. All publicly available data at the time of writing on students who completed both surveys and who were asked about tax opinions were collected and merged for this study. This panel contains 377,435 college students from 619 different American colleges and universities. Of these, 14,691 and 6,493 graduated with a bachelor's degree in accounting or economics, respectively.

These data are not without limitations. While large, the sample is not nationally representative in terms of institutional type. Private, and therefore religious, colleges and universities are over-represented as these institutions more often participate in the CIRP. Specifically, $81 \%$ of the institutions included are private; $57 \%$ are non-secular; and 100\% offer four-year (undergraduate) degrees (by design), while 33\% additionally offer graduate degrees. However, the authors know of no strong reason to believe accounting or economics programs vary significantly across public and private colleges, perhaps decreasing the importance of this limitation. Also, $100 \%$ of respondents are college graduates, since otherwise they would not have been administered the CSS. Given the primary goal of analyzing the effects of accounting and economics higher education, it is arguable that the ideal comparison group would be comprised solely of other college graduates (otherwise estimated differences may also include the general effects of higher education), meaning this data limitation only prohibits additional analysis of differences across education level, inclusive of students who did not finish their degree program. Lastly, while the data disclose the student's major of study at matriculation, the degree they graduated 
with, and related details, not captured were any information on specific courses taken (i.e. transcript data). Therefore, accounting and economics majors are compared to multiple student pools, including students who were never business majors, ${ }^{1}$ perhaps making this last limitation less important as well. Still, readers are advised to take these data limitations into account when interpreting findings.

As part of these surveys, students were given the following statement for which they were asked their opinion: "Wealthy people should pay a larger share of taxes than they do now." The exact same survey question was asked on both the TFS and CSS, meaning these survey instruments captured opinions near both matriculation and graduation for the same student pool. Respondents could choose among four agreement categories: disagree strongly, disagree somewhat, agree somewhat, and agree strongly. It is important to note that respondents were not allowed to take a stance of neutrality, a choice made by the survey administrators.

It is also important to note the term "wealthy" is subjective and was not quantified in these surveys. However, allowing this term to be qualitatively interpreted by survey respondents is common in research that measures opinions of taxation. The use of the term wealthy without quantification can be found in surveys administered to the general population e.g. (Brown-Iannuzzi et al., 2015) and in surveys administered specifically to students (e.g. Hammock et al., 2016; Mendelberg et al., 2017). Additionally, use of the term wealthy without quantification has been used in political election studies for over two decades (American National Election Studies, 2012). Finally, the perception of wealth has often a greater influence on taxation opinions than actual, quantifiable wealth (Brown-Iannuzzi et al., 2015), and using the term without quantification is how one would capture perceptions of wealth.

Table 1 presents the percent of students who chose each response option, on both surveys, for the full sample and across several sub-samples. Figure 1 also provides the full sample statistics in graphical form for ease of reference. At matriculation, more students chose "agree somewhat" with the sentiment that the wealthy should pay higher taxes than they do now than any other response. The response rate was almost $40 \%$ of students. The second most common response, at approximately 26\%, was "agree strongly." In other words, an estimated $66 \%$ (or two-thirds) of incoming college students are of the opinion the wealthy's taxes should increase. By graduation, this proportion had decreased to 56\%, though "agree somewhat" was still the most common response. Thus, the average college student changes their opinion more against further taxing the wealthy during their college tenure. Since it is possible there are close to as many students who increase agreement with the survey statement as decrease agreement, these raw response proportions may be masking how much total opinion change is actually taking place. Therefore, in the last column in Table 1, presented are the percent of students who changed their opinion (chose different responses on the TFS and CSS) during college tenure. At approximately $63 \%$, the majority of college students indeed changed their agreement level, demonstrating that college is a very transformative time for this opinion.

Table 1: Student opinions on further taxation of the wealthy.

\begin{tabular}{|c|c|c|c|c|}
\hline Sample & $\begin{array}{l}\text { Percent frequency } \\
\text { within sample } \\
\text { Disagree } \\
\text { strongly }\end{array}$ & $\begin{array}{l}\text { Disagree } \\
\text { somewhat }\end{array}$ & $\begin{array}{l}\text { Agree } \\
\text { somewhat }\end{array}$ & $\begin{array}{l}\text { Agree } \\
\text { strongly }\end{array}$ \\
\hline $\begin{array}{l}\text { All graduates }(n= \\
377,435)\end{array}$ & & & & \\
\hline At matriculation & 12.1 & 22.3 & 39.3 & 26.3 \\
\hline $\begin{array}{l}\text { At graduation } \\
\text { Never an accounting } \\
\text { or economics major } \\
(n=356,251)\end{array}$ & 15.2 & 28.8 & 34.2 & 21.8 \\
\hline At matriculation & 11.8 & 22.1 & 39.8 & 26.3 \\
\hline $\begin{array}{l}\text { At graduation } \\
\text { Business major } \\
\text { graduates }(n= \\
59,189)\end{array}$ & 15.0 & 29.0 & 34.5 & 21.4 \\
\hline At matriculation & 15.2 & 24.9 & 36.6 & 23.2 \\
\hline $\begin{array}{l}\text { At graduation } \\
\text { Never a business } \\
\text { major }(n=318,246)\end{array}$ & 17.0 & 31.8 & 33.1 & 18.1 \\
\hline At matriculation & 11.5 & 21.7 & 40.0 & 26.7 \\
\hline $\begin{array}{l}\text { At graduation } \\
\text { Accounting major } \\
\text { graduates }(n= \\
14,691)\end{array}$ & 14.8 & 28.5 & 34.7 & 21.9 \\
\hline
\end{tabular}




\begin{tabular}{|c|c|c|c|c|c|}
\hline At matriculation & 15.5 & 26.1 & 35.8 & 22.6 & 64.7 \\
\hline At graduation & 16.5 & 31.5 & 34.0 & 18.1 & \\
\hline \multicolumn{6}{|c|}{$\begin{array}{l}\text { Always an } \\
\text { accounting major ( } n \\
=3,836)\end{array}$} \\
\hline At matriculation & 12.0 & 23.9 & 40.7 & 23.4 & \multirow[t]{3}{*}{69.9} \\
\hline At graduation & 12.8 & 30.1 & 38.8 & 18.3 & \\
\hline \multicolumn{5}{|c|}{$\begin{array}{l}\text { Switched to an } \\
\text { accounting major ( } n \\
=10,855)\end{array}$} & \\
\hline At matriculation & 16.3 & 26.8 & 34.5 & 22.4 & \multirow[t]{3}{*}{62.9} \\
\hline At graduation & 17.6 & 32.1 & 32.5 & 17.8 & \\
\hline \multicolumn{5}{|c|}{$\begin{array}{l}\text { Economics major } \\
\text { graduates }(n=6,493)\end{array}$} & \\
\hline At matriculation & 20.9 & 27.1 & 31.7 & 20.3 & \multirow[t]{2}{*}{70.0} \\
\hline At graduation & 20.0 & 30.0 & 31.0 & 19.0 & \\
\hline \multicolumn{6}{|c|}{$\begin{array}{l}\text { Always an } \\
\text { economics major }(n= \\
726)\end{array}$} \\
\hline At matriculation & 24.4 & 32.6 & 27.9 & 15.1 & \multirow[t]{3}{*}{74.1} \\
\hline At graduation\} & 23.2 & 37.8 & 24.4 & 14.6 & \\
\hline \multicolumn{5}{|c|}{$\begin{array}{l}\text { Switched to an } \\
\text { economics major }(n= \\
5,767)\end{array}$} & \\
\hline At matriculation & 20.5 & 26.2 & 32.4 & 21.0 & \multirow[t]{2}{*}{69.8} \\
\hline At graduation & 19.3 & 29.0 & 32.6 & 19.0 & \\
\hline
\end{tabular}

Notes: Values are "percent of students" within each sample, at that point in time.Values shown may not sum to 100.0 due to rounding.

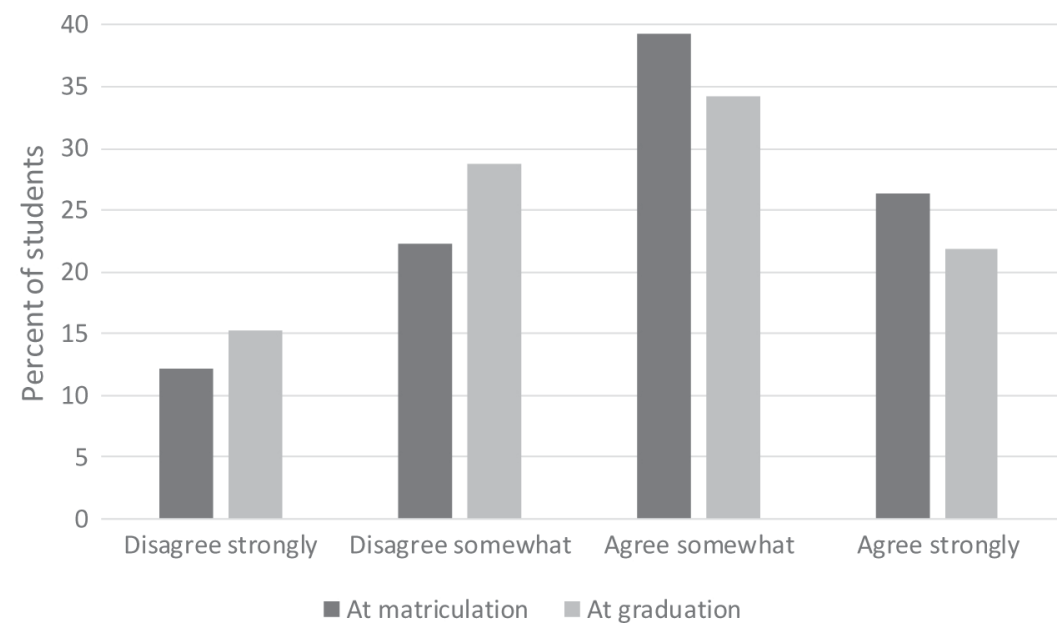

Figure 1: Student opinions on further taxing the wealthy. Notes: $\mathrm{N}=377,435$.

Regarding the relevant sub-samples, business majors are shown more likely to disagree with the statement than non-business majors, at both points in time. Many U.S. college students switch degree programs at some point during tenure. ${ }^{2}$ It is very arguably the case that the overall college experience (e.g. courses taken, peers interacted with) is different for students who were always accounting majors and those who began studying something else but later switched to accounting, for example. Thus, shown are opinion proportions not only for graduates of these degree programs, but across students who were always majoring in the discipline and those who later switched majors into the discipline. Students who were always accounting majors are approximately seven percentage points more likely to change their opinion compared to the aggregate student pool. Accounting major graduates are shown less likely to agree with raising taxes on the wealthy, at both points in time, and compared to both the general student pool and those who were never studying one of the two disciplines in question. Interestingly, those who switched into accounting are even less likely to agree than students who were always accounting majors. Students who were always economics majors are the most unique in Table 1.

Their modal agreement level was to "disagree somewhat"; with raising wealthy taxes at both points in time. At over a $74 \%$ rate, they are also the most likely to change their opinion during college tenure. In aggregate, the proportions in Table 1 show that economics majors are both more likely to disagree with the survey statement 
and change their opinion than are accounting majors, who in turn are more likely to do both than the pool of all other college students.

Over 75 majors of study are represented in this student sample. For brevity, proportions across all other college majors are not presented. Noteworthy, however, is that students who were always economics and always accounting majors were the first and second most likely, respectively, to change opinions on this survey statement during college when ranked against other majors. ${ }^{3}$ This finding adds credence to the assumption that these programs of study are the most likely to alter opinions on taxation.

Opinion differences across accounting majors, economics majors, and other sub-samples are apparent, though some are not vast. To better judge if opinions can truly be thought different across major of study, statistical hypothesis tests (Mann-Whitney tests) are performed. In these tests, the null hypothesis is that the two sub-samples being compared share the same opinions on average, with the alternative hypothesis being that opinions are not the same. This test is performed on every sub-sample examined in Table 1 compared with its opposite, as well as matriculating and graduating opinions within each sub-sample. The conclusion of every test was to reject the null hypothesis. That is, each sample in Table 1 is found to be statistically different from its opposite, and within each there was a statistically significant change in opinions during college. Since this was the case, we choose not to present these test results in tabular form, though they are available from the authors.

The last column in Table 1 demonstrates that there is more total opinion change happening among college students than differences in the average survey responses (within each sub-sample) imply. To further examine this, the proportions of students who either decreased or increased their agreement with the survey statement are presented in Table 2. Referring to the full sample, about 37\% (26\%) of college students decrease (increase) agreement with further taxation of the wealthy. Students who were always accounting majors are more likely to both increase or decrease agreement. Students who were always economics majors are equally as likely to decrease agreement when compared to accounting majors, but additionally more likely to increase agreement. For the full sample, Figure 2 discloses the percent of students within each matriculating agreement level who chose each graduating agreement level.

Table 2: Opinion strength changers (percent of students) by direction.

\begin{tabular}{|c|c|c|c|c|}
\hline Sample & $\begin{array}{l}\text { Decreased } \\
\text { agreement } \\
\text { (i) }\end{array}$ & $\begin{array}{l}\text { Increased } \\
\text { agreement } \\
\text { (ii) }\end{array}$ & $\begin{array}{l}\text { Gap } \\
\text { (i)- (ii) }\end{array}$ & $\begin{array}{l}\text { Ratio } \\
\text { (i)/(ii) }\end{array}$ \\
\hline All graduates & 36.8 & 26.0 & 10.8 & 1.415 \\
\hline $\begin{array}{l}\text { Never an accounting or economics } \\
\text { major }\end{array}$ & 37.0 & 25.6 & 11.4 & 1.445 \\
\hline Business major graduates & 37.3 & 27.3 & 10.0 & 1.366 \\
\hline Never a business major & 36.9 & 25.5 & 11.4 & 1.447 \\
\hline Accounting major graduates & 35.7 & 29.0 & 6.7 & 1.231 \\
\hline Always an accounting major & 39.5 & 30.4 & 9.1 & 1.299 \\
\hline Switched to an accounting major & 34.5 & 28.3 & 6.2 & 1.219 \\
\hline Economics major graduates & 37.9 & 32.1 & 5.8 & 1.181 \\
\hline Always an economics major & 39.5 & 34.6 & 4.9 & 1.142 \\
\hline Switched to an economics major & 37.4 & 32.4 & 5.0 & 1.154 \\
\hline
\end{tabular}

Notes: Values in (i) \& (ii) are "percent of students" in sample. See Table 1 for sample sizes. 


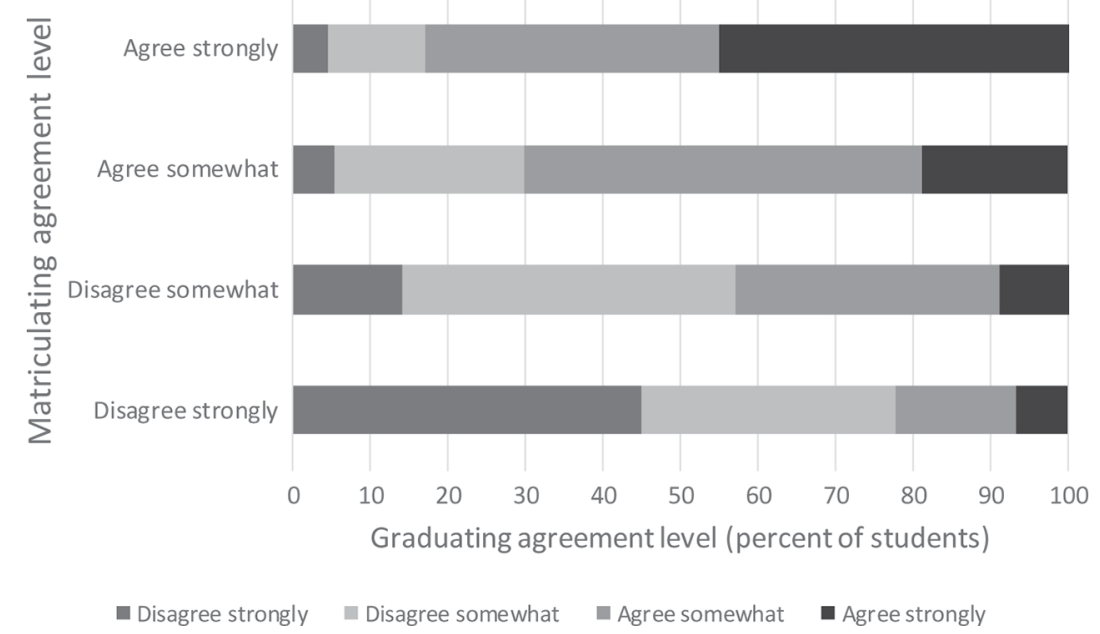

Figure 2: Changes in student opinion.

Another way to examine changing opinions is to specifically look at change from one side of the debate to the other. That is, what proportion of students switch from one of the two "disagree" response options to one of the "agree" options or vice versa? Table 3 shows these values. Over $23 \%$ of college students matriculated believing the U.S. should further tax the wealthy but felt the opposite by graduation. About $14 \%$ changed sides of the debate in the other direction. Differences across the sub-samples investigated here are relatively small in this regard. The gap between these two proportions is larger for students majoring in something other than accounting or economics than either of these two majors. This is perhaps unsurprising, however, given it has already been shown that all sub-samples are more likely to decrease agreement than increase it, and accounting and economics majors matriculate with less average agreement.

Table 3: Stance changers (percent of students) by direction.

\begin{tabular}{lllll}
\hline Sample & $\begin{array}{l}\text { From agree } \\
\text { to disagree } \\
\text { (i) }\end{array}$ & $\begin{array}{l}\text { From disagree } \\
\text { to agree } \\
\text { (ii) }\end{array}$ & Gap & Ratio \\
\hline All graduates & 23.3 & 13.9 & 9.4 & (i) / (ii) $)$ \\
Never an accounting or economics & 23.8 & 13.8 & 10.0 & 1.676 \\
major & & & & 1.725 \\
Business major graduates & 23.9 & 15.5 & 8.4 & 1.542 \\
Never a business major & 23.5 & 13.7 & 9.8 & 1.715 \\
Accounting major graduates & 22.2 & 16.0 & 6.2 & 1.386 \\
Always an accounting major & 24.9 & 18.3 & 6.6 & 1.361 \\
Switched to an accounting major & 21.8 & 15.2 & 6.6 & 1.434 \\
Economics major graduates & 24.5 & 21.8 & 2.8 & 1.124 \\
Always an economics major & 25.9 & 21.7 & 4.2 & 1.194 \\
Switched to an economics major & 24.6 & 22.4 & 2.2 & 1.098 \\
\hline
\end{tabular}

Notes: Values in (i) \& (ii) are "percent of students" in sample. See Table 1 for sample sizes.

It may also be of interest to examine if accounting and economics majors end their collegiate tenure more or less united on their opinions, and when compared to other student groups. The measure of variability for an ordinal variable (like this agreement index) is the variation ratio. Table 4 presents variation ratios for both matriculating freshman and graduating senior responses for all of the student sub-samples examined. The variation ratio is calculated as one minus the proportion of modal responses, and therefore takes on values between zero and one, with larger values implying more variability (less unity of agreement in this case). At matriculation, students who always remained accounting majors were the most unified on their opinions, while economics graduates the most diverse. The two types of economics majors become marginally more diverse in agreement level during college, while all other samples investigated a bit more unified. Absolute differences here are largely small. However, as measured by changes in variation ratios, the pool of all college graduates experiences 2.8 (7.3) times as much unification in opinion as do accounting (economics) majors during college tenure. In short, both accounting and economics majors begin college less unified on tax opinions when com- 
pared to other students, college education appears to increase unification overall somewhat, but less unification takes place for accounting and economics students.

Table 4: Variation ratios by sample.

\begin{tabular}{llll}
\hline Sample & $\begin{array}{l}\text { At } \\
\text { matriculation } \\
\text { (i) }\end{array}$ & $\begin{array}{l}\text { At } \\
\text { graduation } \\
(\mathbf{i i})\end{array}$ & Change \\
\hline All graduates & 0.607 & 0.658 & -0.051 \\
Never an accounting or economics major & 0.602 & 0.655 & -0.053 \\
Business major graduates & 0.634 & 0.669 & -0.035 \\
Never a business major & 0.600 & 0.653 & -0.053 \\
Accounting major graduates & 0.642 & 0.660 & -0.018 \\
Always an accounting major & 0.593 & 0.612 & -0.019 \\
Switched to an accounting major & 0.655 & 0.675 & -0.020 \\
Economics major graduates & 0.683 & 0.690 & -0.007 \\
Always an economics major & 0.674 & 0.622 & 0.052 \\
Switched to an economics major & 0.676 & 0.674 & 0.002 \\
\hline
\end{tabular}

Notes: The variation ratio is a measure of statistical dispersion in nominal distributions, and is defined as the proportion of cases which are not the mode. See Table 1 for sample sizes.

\section{Impacts of accounting and economics education}

Descriptive analysis in hand, we now turn to our primary research question: what are the estimated average effects of majoring in accounting and economics on this tax opinion? Accounting and economics majors may differ from other college students in ways other than their program of study. Specifically, they may come from different backgrounds and/or have different collegiate experiences, on average. Indeed, the same is likely true for most any collegiate major. To better estimate the true effects of these programs of study on student opinions, we must therefore control for these potentially confounding factors and turn to regression analysis. These models take the form

$$
y_{i s t}=\alpha+\beta_{1} \text { acct }_{i}+\beta_{2} \text { econ }_{i}+\gamma \mathbf{X}_{i}+\delta y_{i, t-4}+\mathbf{S}_{s}+\mathbf{T}_{t}+\varepsilon_{i s t}
$$

where $y_{\text {ist }}$ is an outcome relating to student $i$ at school s's opinion on further taxing the wealthy at graduation time $t ; \alpha$ a constant term; acct $_{i}$ an indicator for accounting majors; econ ${ }_{i}$ an indicator for economics majors; $\mathbf{X}_{i}$ a set of individual-level controls (which include both pre- and within-college variables); $y_{i, t-4}$ the student's opinion on further taxing the wealthy at college matriculation (partitioned into indicators); $\mathbf{S}_{s}$ institutional indicators (or "school fixed effects"); $\mathbf{T}_{t}$ time (graduating year) fixed effects; and $\varepsilon_{i s t}$ the residual error term.

Here, $\beta_{1}$ and $\beta_{2}$, the estimated effects of majoring in accounting and economics, respectively, are of key interest. School fixed effects allow us to control for unobserved heterogeneity across institutions, and therefore accounting and economics degree programs. Standard errors are also clustered at the institution level for additional control in this regard. Time fixed effects control for any time-variant unobserved heterogeneity, including any national trends in tax opinions or higher education. As shown by the inclusion of $y_{i, t-4}$ in the above equation, we control for students' matriculating tax opinions in all models. This is a particularly important dimension of control since, for example, it is impossible to observe an increase in agreement with the survey statement for students matriculating with an opinion of "agree strongly."

In the interest of robustness, we estimate six versions of the model described by the above equation. First, we wish to estimate the separate impacts of majoring in accounting and economics on the probability a student will change the strength of their their opinion during college tenure. Thus, in our first specification, $y_{i s t}$ is an indicator variable which takes on the value one if student $i$ changed their response to the tax survey statement during college, and zero otherwise. Since this outcome is binary, we use logistic regression for this specification. ${ }^{4}$ In specification (2), $y_{\text {ist }}$ is transformed into a categorical variable with three designations: decreased the strength of agreement with the survey statement, increased agreement, or no change change in agreement. This model is estimated with multinomial logistic regression using "no change in agreement" as the base category. In specification (3), we transform students' CSS survey responses into an increasing agreement level index with values one, two, three, and four. Since the dependent variable is ordinal in nature, specification (3) is estimated 
with ordered logistic regression. In specification (4), $y_{i s t}$ refers to the change in student $i$ 's agreement level during college, as measured by their graduating agreement level index value minus this value at matriculation. Hence, in specification (4), $y_{\text {ist }}$ can take on any whole number value between and including -3 and +3 , where 0 represents "no change." This new dependent variable is still ordinal, and we therefore again use ordered logistic regression. In specification (5), $y_{\text {ist }}$ equals one if student $i$ changed sides of the debate, that is, changed their stance from one of the agree responses to one of the disagree responses during college tenure, or vice versa. Finally, in specification (6), $y_{\text {ist }}$ is again transformed into a categorical variable with three designations: did not change stance, changed stance from agree to disagree, and changed stance from disagree to agree.

For the reasons mentioned previously, students who always remained in a degree program may be different than those who switched into one. "Switchers" may constitute a superior "treatment" group if we in any way believe students who begin their collegiate careers as accounting or economics majors are differently predisposed to being affected by these programs of study, or specifically if we believe their opinions are already more in line (on average) with those already within their future discipline. Indeed, the (previously discussed) statistics in Table 1 and Table 4 demonstrate that matriculating opinion similarity is stronger for non-switchers in both majors, particularly accounting. Also, if the estimated effects across switchers and "always majors" are in the same direction, we can be more confident that what $\beta_{1}$ and $\beta_{2}$ are capturing are indeed the effects of these programs. Therefore, we estimate all six model specifications with two different treatment sets: one where acct $_{i}$ and econ ${ }_{i}$ refer to everyone who graduates with these majors, and one where acct $_{i}$ and econ ${ }_{i}$ only refer to students who started college as some other major but later switched to and graduated with this major. When acct $_{i}$ and econ ${ }_{i}$ refer to all graduates, we drop students who were ever one of these majors but graduated with another degree as well as other business majors, as all of these students are likely to have had some accounting and economics courses. ${ }^{5}$ When acct ${ }_{i}$ and econ ${ }_{i}$ refer to major switchers only, we additionally drop those who were always one of these majors.

Table 5: Individual-level control variable summary statistics.

\begin{tabular}{|c|c|c|c|c|}
\hline Variable & Mean & SD & Min & $\operatorname{Max}$ \\
\hline Male & 0.3846 & 0.4865 & 0 & 1 \\
\hline African-American & 0.0490 & 0.2159 & 0 & 1 \\
\hline American Indian & 0.0128 & 0.1122 & 0 & 1 \\
\hline Asian & 0.0480 & 0.2138 & 0 & 1 \\
\hline Hispanic & 0.0445 & 0.2063 & 0 & 1 \\
\hline Other non-white race & 0.0298 & 0.1700 & 0 & 1 \\
\hline Domestic student (U.S. citizen) & 0.9661 & 0.1811 & 0 & 1 \\
\hline First generation college student & 0.1822 & 0.3860 & 0 & 1 \\
\hline Part-time student & 0.0537 & 0.2254 & 0 & 1 \\
\hline Switched majors & 0.4918 & 0.4999 & 0 & 1 \\
\hline High school GPA & 3.3483 & 0.3857 & 1 & 4 \\
\hline SAT score & $1,119.8980$ & 178.0154 & 89 & 1,600 \\
\hline Father's years of schooling & 15.4210 & 2.7110 & 8 & 19 \\
\hline Mother's years of schooling & 14.7963 & 2.4999 & 8 & 19 \\
\hline Family income at matriculation $(\$ 0,000)$ & 72.7977 & 50.8615 & 6 & 200 \\
\hline Intact family & 0.7910 & 0.4066 & 0 & 1 \\
\hline Joined fraternity/sorority & 0.1915 & 0.3935 & 0 & 1 \\
\hline Played intercollegiate sports & 0.2646 & 0.4411 & 0 & 1 \\
\hline College GPA & 3.2086 & 0.4575 & 2 & 4 \\
\hline Academic self-rating index & 4.0135 & 0.7092 & 1 & 5 \\
\hline Worked during college & 0.8123 & 0.3905 & 0 & 1 \\
\hline Non-continuous collegiate tenure & 0.0505 & 0.2190 & 0 & 1 \\
\hline Financial wealth self-importance index & 2.6518 & 0.9159 & 1 & 4 \\
\hline Altruism self-importance index & 2.9648 & 0.7704 & 1 & 4 \\
\hline Religion: Christianity & 0.8243 & 0.3806 & 0 & 1 \\
\hline Religion: Judaism & 0.0197 & 0.1388 & 0 & 1 \\
\hline Religion: other religion & 0.0466 & 0.2108 & 0 & 1 \\
\hline \multicolumn{5}{|l|}{ Political leaning at matriculation } \\
\hline Far left & 0.0137 & 0.1162 & 0 & 1 \\
\hline Liberal & 0.2388 & 0.4263 & 0 & 1 \\
\hline Conservative & 0.2662 & 0.4419 & 0 & 1 \\
\hline Far right & 0.0156 & 0.1241 & 0 & 1 \\
\hline \multicolumn{5}{|l|}{ Political leaning at graduation } \\
\hline Far left & 0.0246 & 0.1546 & 0 & 1 \\
\hline Liberal & 0.2666 & 0.4422 & 0 & 1 \\
\hline
\end{tabular}




\begin{tabular}{lllll} 
Conservative & 0.2572 & 0.4371 & 0 & 1 \\
Far right & 0.0108 & 0.1036 & 0 & 1 \\
\hline
\end{tabular}

Notes: $\mathrm{N}=377,435$. Omitted political leaning category is "middle-of-the-road." Index variables enter the models as sets of indicators. $\mathrm{SD}=$ standard deviation.

Table 6: Estimated effects of majoring in accounting and economics.

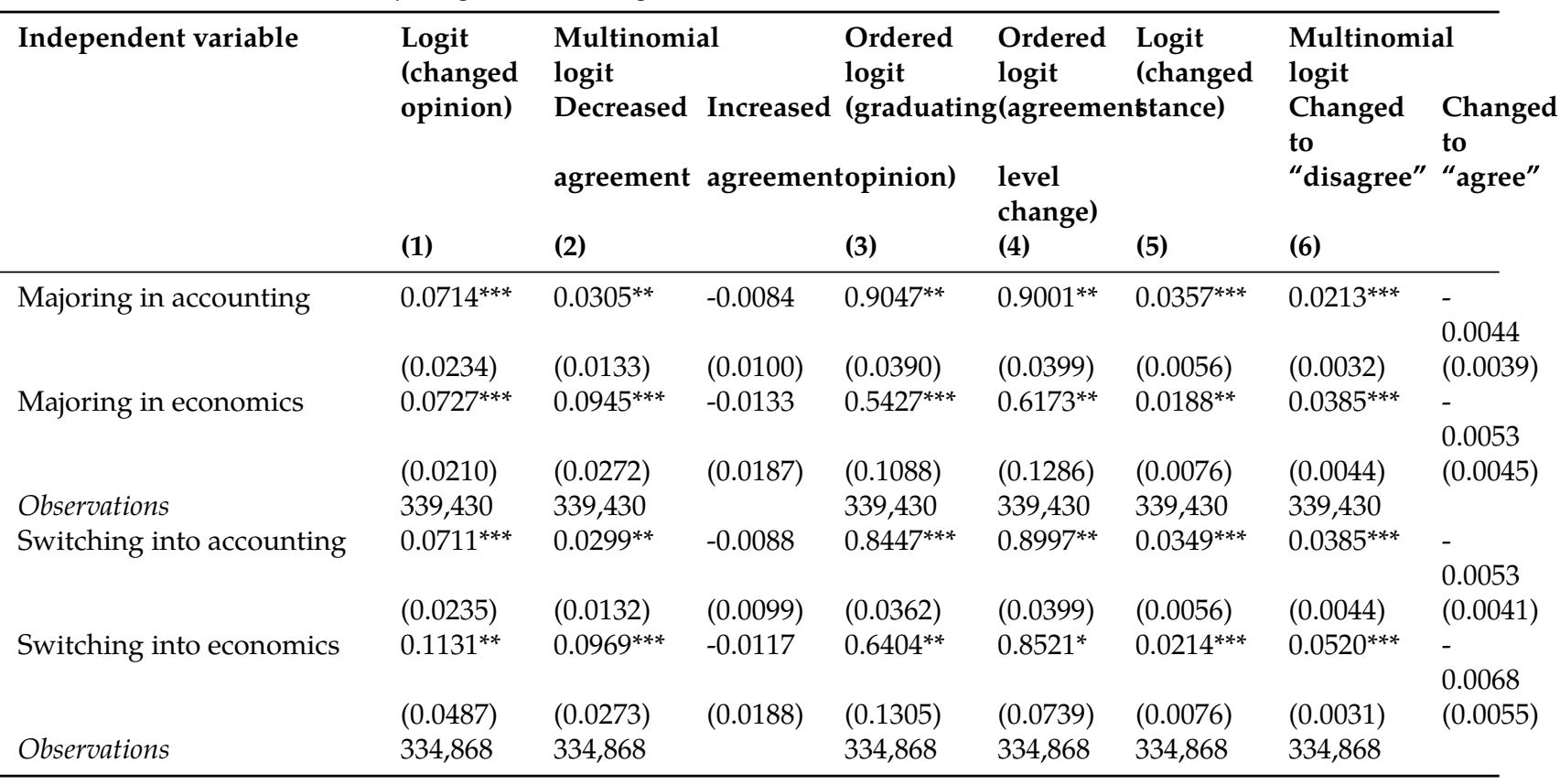

Notes: Clustered standard errors in parentheses. ${ }^{*} p<0.10 ;{ }^{* *} p<0.05 ; * * *<0.01$. Estimates from logits and multinomial logits are marginal effects, while estimates from ordered logits are odds ratios.

Generally speaking, the TFS captured data on students' demographics and pre-college lives, while the CSS captured data pertaining to their collegiate experience. Demographics and household structure are thought, or have been shown in prior research, to be related to tax preferences. For example, O'Brien (2017) shows that race is related to such opinions. In the interest of data disclosure, Table 5 presents summary statistics for the individual-level control variables in $\mathbf{X}_{i}$ that we take from these two surveys. These include the student's gender; race (six categories); citizenship status; high school grade point average (GPA); SAT score; ${ }^{6}$ father's years of schooling; mother's years of schooling; college GPA; religion (four categories); an increasing index (on a one-tofive scale) of the student's self-perceived academic abilities at matriculation; and indicators for first-generation college students, part-time students, those who switched majors, intact families (two parents who live together), fraternity/sorority membership, intercollegiate sports participation, those with employment during college, and those who attended college non-continuously (e.g. took a "gap" semester or internship).

In addition to these more general student characteristics, the surveys also captured variables one would specifically hope to control for in a study of tax policy opinions. These include the student's combined parental income at matriculation, a self-reported increasing index (on a one-to-four scale) describing how important financial wealth is to the student at graduation, ${ }^{7}$ a similar index describing how important helping others in need is to the student (what we name an "altruism index"), and the student's self-reported political leaning at both matriculation and graduation (five identical categories each). Family income, wealth aspirations, altruism, and political leanings are all thought to influence tax policy opinions (see, e.g. Beedle and Taylor-Gooby (1983), Slemrod (1995), and Ashworth and Heyndels (1997), or Lago-Peñas \& Lago-Peñas, 2010). We consider these among our more important controls. Variables describing the change in a student's political leaning and one higher order term, family income squared, are included for additional control.

Table 6 presents the results from our multivariate models. Estimates from specification (1) show that majoring in accounting increases the probability a student will change their tax opinion by approximately seven percentage points. For economics majors, we see a similar but potentially larger effect of somewhere between 7 and 11 percentage points. Estimates from specification (2) show that learning accounting increases the probability a student will decrease agreement with the survey statement by about three percentage points. For economics majors, this effect is much stronger at 9-10 percentage points. Specification (2) also shows that neither major changes the probability one will increase agreement, on average. Specification (3) demonstrates that, 
controlling for their matriculating agreement level among a long list of other factors, accounting and economics majors are 10-16 and 36-46 percent less likely to report as high an agreement level with further taxation of the wealthy as other students at graduation. Results from (4) show studying both disciplines decreases student agreement with further taxing the wealthy - accounting and economics students are made more likely to disagree with policies which increase taxes for wealthy individuals. Specifically, accounting (economics) majors are about 10 (15-38) percent more likely to decrease agreement with the opinion that we should increase the taxes the wealthy pay, compared to other college students. Results from (5) show that, relative to other college students, accounting (economics) majors are about 3.5 (2) percentage points more likely to change their stance to the opposite side of the debate, while (6) demonstrates (as in (2)) these changes are more often from "agree" to "disagree."

In short, after implementing a significant level of control, our model results show studying both accounting and economics makes students relatively more likely to change their tax opinion during collegiate tenure, and on average this opinion change is in the direction against further taxation of the wealthy. To further test the robustness of these estimates, we estimated alternate versions of the models whose results are presented in Table 6. First, to check the validity of our controls, we re-estimated models excluding the individual controls $\left(\mathbf{X}^{i}\right)$, models excluding school fixed effects $\left(\mathbf{S}^{s}\right)$, and models excluding time fixed effects $\left(\mathbf{T}^{t}\right)$. In all cases, the magnitude of the estimated effects of accounting and economics education somewhat increased, with the sign and statistical significance of the estimated effects remaining constant.

Also, we considered that accounting and economics are relatively high earning majors in terms of postgraduation wages. Thus, it is possible the average effect estimates presented in Table 6 are a combination of the educational impacts of the degree programs and the effect of increased earnings potential. Theoretically, individuals with higher earning potential would be more likely against further taxation of the wealthy, on average and ceteris paribus. As a test of whether or not our full models control for enough individual level characteristics such that the estimates attached to acct $_{i}$ and econ $_{i}$ are mostly capturing the educational impacts of these programs and not just the increased wage potential, we estimate similar models for even higher earning majors but ones where tax education is typically not present. Specifically, we estimated the effects of majoring in chemical engineering, biochemistry/biophysics, and computer engineering on tax opinions. ${ }^{8}$ In all three cases we find statistically insignificant results, implying we can be more confident the estimates presented in Table 6 are not simply capturing the impact of increased earning potential. ${ }^{9}$ For brevity, these robustness checks are not presented here, but are available from the authors.

\section{Opinion change heterogeneity}

To better understand the nature of the estimated impacts discussed in the previous section, one might consider the likelihood they differ across student and institution type. Table 7 presents results from models of specification (4) performed on additional student subsamples. Specification (4) may be considered the primary specification in this analysis, as it captures the impacts of the two degree programs on overall agreement level change and direction. Recall the other specifications are designed to capture more specific estimates, such as impacts on the probability of a stance shift (specifications 5 and 6), graduating opinions (specification 4), a directional change (specification 2), or any opinion change (specification 1).

Students from different socioeconomic groups are likely to begin their college education with differing opinions on taxation of the wealthy, and therefore may change these opinions at different rates and perhaps in different directions. To test this, the sample is split into its five household (real) income quintiles (from the poorest $20 \%$ of students to the richest $20 \%$ ) and the impacts of accounting and economics education are reestimated within each quintile. For accounting students, the strength of the average opinion change increases monotonically moving up the income distribution, as shown in the top panel of Table 7. Students from the richest $20 \%$ of households are about $24 \%$ more likely to decrease agreement with further taxation of the wealthy when compared to other majors; those in the 2nd highest quintile are about $17 \%$ more likely; those in the middle quintile about $11 \%$; and there is no statistically significant impact for the lowest two quintiles. A similar pattern is seen for economics majors, except the impact of economics education is statistically significant across the entire household income distribution, with the average impact strength having a smaller range from an approximate $34 \%$ (richest quintile) to $27 \%$ (poorest quintile). That students from higher income brackets are more likely to adopt the opinion of no further taxation of the wealthy at higher rates is perhaps of little surprise.

Table 7: Agreement change, odds ratios from subsample models.

\begin{tabular}{llllll}
\hline Household income quintile: & 1 & 2 & 3 & 4 & 5 \\
\hline
\end{tabular}




\begin{tabular}{|c|c|c|c|c|c|}
\hline Accounting major impact & $\begin{array}{l}0.9939 \\
(0.0692)\end{array}$ & $\begin{array}{l}0.9440 \\
(0.0614)\end{array}$ & $\begin{array}{l}0.8942^{*} \\
(0.0565)\end{array}$ & $\begin{array}{l}0.8277^{* *} \\
(0.0627)\end{array}$ & $\begin{array}{l}0.7595^{* * *} \\
(0.0589)\end{array}$ \\
\hline Economics major impact & $\begin{array}{l}0.7272^{* * *} \\
(0.0414)\end{array}$ & $\begin{array}{l}0.7193^{* * *} \\
(0.0389)\end{array}$ & $\begin{array}{l}0.7097^{* * *} \\
(0.0365)\end{array}$ & $\begin{array}{l}0.6721^{* * *} \\
(0.0314)\end{array}$ & $\begin{array}{l}0.6617^{* * *} \\
(0.0322)\end{array}$ \\
\hline Institutional political leaning: & & Left & Center & Right & \\
\hline Accounting major impact & & $\begin{array}{l}0.9409 \\
(0.0693)\end{array}$ & $\begin{array}{l}0.9042^{*} \\
(0.0465)\end{array}$ & $\begin{array}{l}0.8103^{* * *} \\
(0.0375)\end{array}$ & \\
\hline Economics major impact & & $\begin{array}{l}0.7206^{* * *} \\
(0.0310)\end{array}$ & $\begin{array}{l}0.6961^{* * *} \\
(0.0367)\end{array}$ & $\begin{array}{l}0.6960^{* * *} \\
(0.0219)\end{array}$ & \\
\hline Student gender: & & Female & Male & & \\
\hline Accounting major impact & & $\begin{array}{l}0.9516 \\
(0.0467)\end{array}$ & $\begin{array}{l}0.8864^{* * *} \\
(0.0355)\end{array}$ & & \\
\hline Economics major impact & & $\begin{array}{l}0.7028^{* * *} \\
(0.0214)\end{array}$ & $\begin{array}{l}0.6940^{* * *} \\
(0.0240)\end{array}$ & & \\
\hline Student ethnicity: & White & Black & Hispanic & Asian & Other \\
\hline Accounting major impact & $\begin{array}{l}0.8718^{* * *} \\
(0.0301)\end{array}$ & $\begin{array}{l}1.0084 \\
(0.1388)\end{array}$ & $\begin{array}{l}0.9129 \\
(0.1283)\end{array}$ & $\begin{array}{l}0.9453 \\
(0.0984)\end{array}$ & $\begin{array}{l}1.0393 \\
(0.1804)\end{array}$ \\
\hline Economics major impact & $\begin{array}{l}0.6889^{* * * *} \\
(0.0169)\end{array}$ & $\begin{array}{l}0.6954^{* * *} \\
(0.0792)\end{array}$ & $\begin{array}{l}0.6608^{* * *} \\
(0.0681)\end{array}$ & $\begin{array}{l}0.6630^{* * *} \\
(0.0689)\end{array}$ & $\begin{array}{l}0.9327 \\
(0.1614)\end{array}$ \\
\hline
\end{tabular}

Notes: Clustered standard errors in parentheses. ${ }^{*} p<0.10 ;{ }^{* *} p<0.05 ;{ }^{* * *} p<0.01$. Compare to specification (4) from Table 6, detailed in Section 4 .

Next, the sample is split across the general political leaning of the institution attended. In the U.S. and elsewhere, conservative (liberal) political views are generally associated with less (more) favorable opinions of the progressive tax system. To identify a college or university's general leaning, the average political leaning of graduating students for each of the 619 sampled schools is calculated using the political leaning control variable discussed previously. Figure 3 presents the distribution of this new institution-level variable, which has a potential (continuous) range of $1-5$ where higher numbers represent higher average conservatism among the institution's graduating students. Schools are then broken into three equally sized categories (left-, middle-, and right-leaning) representing those below the 33rd percentile of this new variable, those between the 33rd and 66th percentile, and those above the 66th percentile. The vertical lines in Figure 3 disclose the positions of these splits. Results in Table 7 show that, for both majors, students at right-leaning schools are more likely to decrease agreement with further taxation of the wealthy than at middle-leaning schools, who in turn are more likely than those at left-leaning schools. In fact, the estimated impact of accounting education is statistically insignificant at left-leaning schools. Opinion change differentials are smaller here than those seen when students are split by household income.

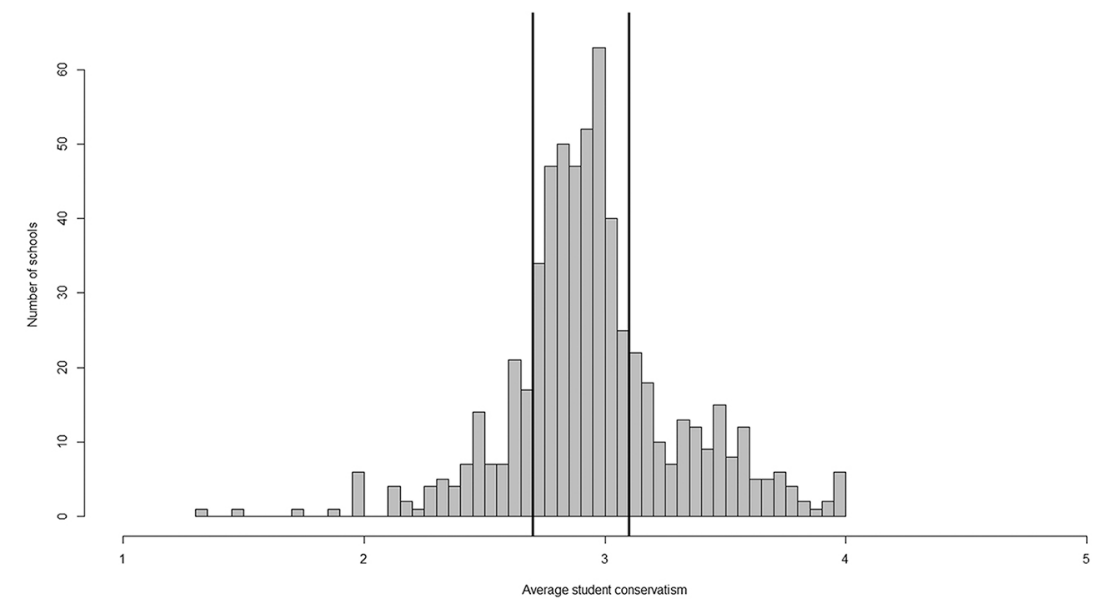

Figure 3: Institution-level political leaning distribution.

Finally, the sample is split across gender and then race/ethnicity, of which there are five available categories in this student sample (White, Black, Hispanic, Asian, and Other Race). The bottom two panels of Table 7 present these results. The within-gender analysis finds that the tax opinion effect of accounting is constrained to males. That is, the estimated impact on female students is not statistically significant. The impact of accounting 
education also appears constrained to students identifying as White. Within the sample, males, and particularly students identifying as White, more often belong to the higher household income quintiles. Results in the same table have shown that accounting education only appears to influence the average opinions of students in these higher income categories. This may be the reason for the gender and racial differences estimated. The impact of economics is highly consistent across both gender and race, however, and is statistically insignificant in only the Other Race category. That the tax opinion effect of economics education appears more universal than that of accounting education is a noteworthy finding. Though not available in this national sample, data which contain information on course content and/or the timing or reported reason behind opinion change are likely to shed light on this difference across the disciplines.

\section{Conclusions}

We set out to document any changes in opinions of accounting and economics majors on taxation of the wealthy. According to enlightenment theory, changes in opinion are evidence that learning has occurred, and this learning is likely the result of the students' educational experience. From a pedagogical viewpoint, our findings are evidence that learning has occurred, but our findings do not provide evidence on whether the learning is sociologically desirable or whether the educational programs are effective, as the former would require analysis of what is desirable, and the latter would require comparison of educational program goals to outcomes. However, the students' thinking has been altered as evidenced by the estimated 70 and 74 percent of students who were always accounting or economics majors, respectively, who alter their tax opinions during college tenure, and that we find additional evidence of causal effects of these programs on tax opinions.

Our findings may also be demonstrable evidence of a noted shift in both positive and normative philosophical viewpoints among academics and policymakers. A positive viewpoint emphasizes that decisions and actions be driven by quantitative analysis that is free from personal beliefs and values (Friedman, M, 1953; Glover, 2014). Conversely, a normative viewpoint focuses on decisions and actions that are driven by moral and ethical ideals (Smith, 2010; Glover, 2014). Historical analysis has revealed that in general, academic accountants currently hold positive viewpoints while accounting policymakers currently hold a normative viewpoint, with both viewpoints representing a change from previously held views (Glover, 2014). Although Glover (2014) focused on accountants, subsequent research supported that academically trained student economists have shifted away from normative views and towards positivist views (Malek et al., 2016). One cause for the shift in viewpoints is the presence of a strong focus on quantitative analysis in modern collegiate education (Glover, 2014; Malek et al., 2016). Quantitative analysis, the foundation of a positive view, may be so strongly embedded in education programs as a whole that student viewpoints are not easily changed as demonstrated course with embedded normative training as part of quantitative degree program (Malek et al., 2016).

The viewpoints of students are not trivial as students will presumably become future professionals, who may make decisions that impact society. Therefore, scholars argue that both positive and normative research must continue in tandem to ensure desirable socio-economic outcomes e.g. (Macve, 2014). This argument is particularly salient here because accountants and economists have historically advised policy makers (Glover, 2014; Zeff, 2014), and the decisions of policymakers have a direct impact on society. Logically, ideal policy advice includes diversity of perspective supported by critical thought. Our findings demonstrate a diversity of perspective since $35.7 \%$ (37.9\%) of accounting (economics) graduates changed the strength of their opinions more against further taxation, but $29.0 \%(32.1 \%)$ changed their opinion in the other direction. Based on economic surveys, it is not surprising the numbers of these students who now further believe additional taxation of the wealthy is optimal is not too dissimilar from the numbers who do not. Polls of professional economists, for example, show that $90 \%$ believe expansionary fiscal policy (decreasing taxes and/or increasing government expenditure to stimulate an economy) works and 79\% are in favor of a " negative income tax" (Mankiw, 2017), but opinions tend to vary much more once they are posed with more specific tax policy questions, such as how much of the burden should be that of the wealthy. In short, though we uncover evidence that accounting and economics education more often moves opinions against further taxation of the wealthy, the percent of students who characterize the opposite shift is nowhere near trivial, and this comes as little surprise given the diverse opinions in these professions.

Our findings align with prior literature in that the graduates experienced a formation of opinion (Nasatir, 1968), but not a unanimous opinion (Rose, 1963), which seems to indicate critical thinking on an individual level (Davis \& Robinson, 1991; Weakliem, 2002). As Chernin and Lahav (2014) reveal in their case study, the actions of a single critical thinker can socio-economically and politically impact the financial markets of an 
entire country. Therefore, the creation of critical thinkers by colleges suggests a bright future for the political and socio-economic fields.

While our study provides an examination and discussion of the measurable indicators of the change in student opinion, we do not test the factors of the focused study of the tax system that prompted the change in opinion for accounting and economics majors. Future research can explore the specific factors of the educational experience that prompt the change in student opinion. In particular, an examination of why the change in opinion for economics majors was relatively universal compared to the change for accounting majors may be warranted. We speculate that the difference in the change may be because economics focuses on the theory behind the effects of taxation, while accounting focuses on current policy and calculations. Possible factors to test include the timing of coursework, topic composition of courses, and methods of topic coverage. Alternatively, students could be directly questioned on why they feel the wealthy should or should not be further taxed, and what has brought about a change in this opinion. A questionnaire which asks students to define "wealthy" may also prove valuable. Further study of the socio-economic and political impact of critical thinking accountants and economists is also warranted, and could perhaps be accomplished with a longitudinal study. We leave these tasks for future study.

\section{Appendix}

Here, we present a table that further details the magnitude of agreement change with the survey statement, across the relevant student samples. Recall, students could choose among four agreement categories: disagree strongly, disagree somewhat, agree somewhat, and agree strongly. We replace these four category names with the values one, two, three, and four respectively, creating an increasing agreement index. A student's agreement change magnitude is their graduating senior (CSS) agreement level minus their matriculating freshman (TFS) agreement level. Thus, an agreement change magnitude of zero refers to no opinion change, negative values designate a decrease in agreement, and positive values increased agreement.

Table 8: Agreement level change magnitudes.

\begin{tabular}{|c|c|c|c|c|c|c|c|}
\hline \multirow[t]{2}{*}{ Sample } & \multicolumn{7}{|c|}{ Agreement change magnitude } \\
\hline & -3 & -2 & -1 & $\mathbf{0}$ & +1 & +2 & +3 \\
\hline All graduates & 3.0 & 9.9 & 23.9 & 37.2 & 18.5 & 5.9 & 1.6 \\
\hline $\begin{array}{l}\text { Never an accounting or } \\
\text { economics major }\end{array}$ & 3.1 & 10.0 & 24.0 & 37.3 & 18.3 & 5.8 & 1.6 \\
\hline Business major graduate & 2.7 & 10.4 & 24.3 & 35.4 & 18.9 & 6.6 & 1.8 \\
\hline Never a business major & 3.1 & 9.8 & 24.0 & 37.5 & 18.3 & 5.7 & 1.6 \\
\hline Accounting major graduates & 3.1 & 9.4 & 23.2 & 35.3 & 20.5 & 6.3 & 2.2 \\
\hline Always an accounting major & 3.1 & 9.4 & 27.0 & 30.1 & 20.8 & 7.3 & 2.3 \\
\hline Switched to an accounting major & 3.3 & 9.3 & 22.0 & 37.1 & 20.3 & 6.0 & 2.0 \\
\hline Economics major graduates & 3.3 & 9.8 & 24.8 & 30.0 & 18.3 & 10.8 & 2.9 \\
\hline Always an economics major & 3.7 & 9.9 & 25.9 & 25.9 & 22.2 & 7.4 & 4.9 \\
\hline Switched to an economics major & 3.2 & 9.9 & 24.3 & 30.2 & 18.2 & 11.8 & 2.4 \\
\hline
\end{tabular}

Notes: Values are "percent of students." See Table 1 for sample sizes. 


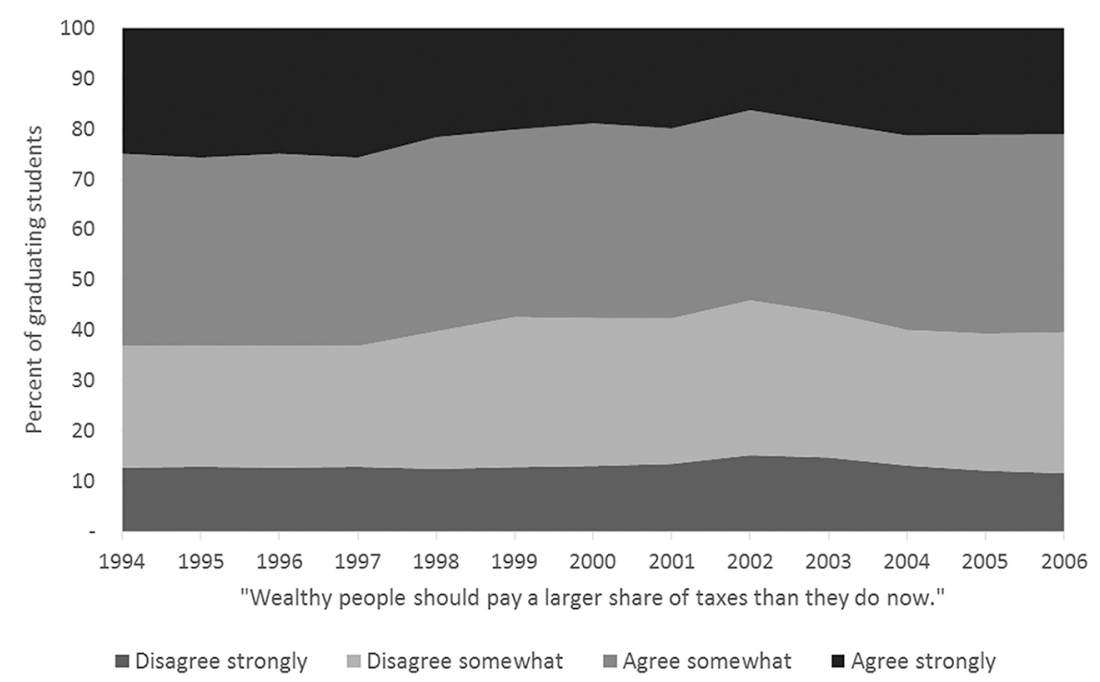

Figure 4: Graduating student opinions across time.

We also present graduating student opinions across time within the sample period. As Figure 4 demonstrates, there was little change in the proportions of agreement among recent graduates between 1994 and 2006.

\section{Notes}

1 To the authors' knowledge, national data on accounting and economics course participation among non-business majors is not readily available. However, anecdotally, it is rare for a non-business major to take any accounting courses, and non-business majors in the U.S. typically take at most one economics course, often to fulfill a social science elective requirement.

2 As examples, the National Center for Education Statistics reports 42, 35, and 28 percent of education, health science, and STEM (science, technology, engineering, and mathematics) majors switch fields at some point in their college education, respectively (Chen \& Soldnew, 2013).

3 The five majors most likely to change their opinion on taxing the wealthy were economics, accounting, pre-law/law enforcement, general business, and pre-medicine (including dentistry and veterinary). The five majors least likely to change their opinion on taxing the wealthy were library science, music/art, physical education, marine science, and astronomy.

4 For additional robustness, the logit specifications were also estimated in the form of linear probability models (LPMs), results from which mirror the logistic estimates presented here. Similarly, probit models yield similar estimates.

5 We note, however, that including students who were business graduates in programs other than economics and accounting does not change the results presented in Table 6 in a significant way. Specifically, signs and statistical significance levels remain unchanged, and the magnitudes of the estimated effects change only slightly (they are slightly smaller in absolute terms).

6 The Scholastic Aptitude Test, or SAT, is the typical test for college admission in the U.S. For students who took the American College Testing exam (ACT), but not SAT, we convert their ACT score into the equivalent SAT score using the ACT-to-SAT conversion table on the official ACT website (ACT.org, 2015).

7 Students could respond that accumulating financial wealth post-graduation was: not important, somewhat important, very important, or essential. All controls which constitute an index enter our models as sets of indicator variables.

8 Our sample includes 1,782, 2,441, and 113 students with one of these three majors, respectively.

9 This appears to be due in large part because we are able to control for matriculating tax opinions and financial wealth desires at graduation. That is, when these controls are excluded, chemical engineering education (but not biochemistry/biophysics or computer engineering) is shown to have a statistically significant (though only at the $90 \%$ confidence level) impact on tax opinions.

Article Note: Working Paper: Please do not quote or cite without authors' permission.

\section{References}

ACT.org. (2015). Compare ACT \& SAT scores. Available at: http://www.act.org/ solutions/college-career-readiness/compare-act-sat/.

Ashworth, J., \& Heyndels, B. (1997). Politicians' preferences on local tax rates: An empirical analysis. European Journal of Political Economy, 13(3), 479-502.

Bartels, L. M. (2005). Homer gets a tax cut: Inequality and public policy in the American mind. Perspectives on Politics, 3(1), 15-31.

Beedle, P., \& Taylor-Cooby, P. (1983). Ambivalence and altruism: Public opinion about taxation and welfare. Policy \& Politics, 11(1), 15-39.

Biondi, Y. (2016). Empowering market-based finance: A note on bank bailouts in the aftermath of the North Atlantic Financial Crisis of 2007. Accounting, Economics, and Law: A Convivium, 6(1), 79-84.

Biondi, Y., \& Suzuki, T. (2007). Socio-economic impacts of international accounting standards: an introduction. Socio-Economic Review, 5(4), 585-602. 
Bobek, D. D., Chen, J. C., Hageman, A. M., \& Tian, Y. (2016). Are more choices better? An experimental investigation of the effects of multiple tax incentives. The Journal of the American Taxation Association, 38(2), 111-128.

Brown-lannuzzi, J. L., Lundberg, K. B., Kay, A. C., \& Payne, B. K. (2015). Subjective status shapes political preference. Psychological Science, 26(1), $15-26$.

Chen, X., \& Soldnew, M. (2013). STEM attrition: College students' paths into and out of STEM fields, Statistical analysis report. Available at: https://nces.ed.gov/pubs2014/2014001rev.pdf

Chernin, Y., \& Lahav, Y. (2014). "The people demand social justice" A case study on the impact of protests on financial markets. Accounting, Economics, and Law: A Convivium, 4(2), 99-121.

Clemons, R., \& Shevlin, T. (2016). The tax policy debate: Increasing the policy impact of academic tax accounting research. The Journal of the American Taxation Association, 38(1), 29-37.

Davis, N. J., \& Robinson, R. V. (1991). Men's and women's consciousness of gender inequality: Austria, West Cermany, Great Britain, and the United States. American Sociological Review, 56(1), 72-84.

Dean, S. (2005). Attractive complexity: Tax deregulation, the check-the-box election, and the future of tax simplification. Hofstra Law Review, 34(1), 405-467.

Douglas-Gabriel, D. (2016). Want college to pay off? These are the 50 majors with the highest earnings. The Washington Post.

Edlund, ]. (2003). Attitudes towards taxation: Ignorant and incoherent? Scandinavian Political Studies, 26(2), 145-167.

Franek, R. (2017). Top 10 college majors. The Princeton Review. Available at: https://www.princetonreview.com/college-advice/top-ten-collegemajors

Friedman, M. (1953). Essays in positive economics. University of Chicago Press.

Clover, ]. (2014). Have academic accountants and financial accounting standard setters traded places? Accounting, Economics, and Law: A Convivium, 4(1), 17-26.

Hammock, M. R., Routon, P. W., \& Walker, J. K. (2016). The opinions of economics majors before and after learning economics. The Journal of Economic Education, 47(1), 76-83.

Hanlon, M., \& Heitzman, S. (2010). A review of tax research. Journal of Accounting and Economics, 50(2), 127-178.

Internal Revenue Service. (2017). SOI tax stats. Available at: https://www.irs.gov/uac/soi-tax-stats-individual-statistical-tables-by-tax-rateand-income-percentile.

Jackstadt, S. L., Brennan, J., \& Thompson, S. (1985). The effect of introductory economics courses on college students' conservatism. The Journal of Economic Education, 16(1), 37-51.

Keene, K. (1983). What do we know about the public's attitude on progressivity? National Tax Journal, 36(3), 371-376.

Kinsey, K. A., Grasmick, H. G., \& Smith, K. W. (1991). Framing justice: Taxpayer evaluations of personal tax burdens. Law \& Society Review, 25(4), 845-874.

Lago-Peñas, I., \& Lago-Peñas, S. (2010). The determinants of tax morale in comparative perspective: Evidence from European countries. European Journal of Political Economy, 26(4), 441-453.

Leonhardt, D. (2014). Is college worth it? Clearly yes, new data says. The New York Times. p.3.

Luker, W., \& Proctor, W. (1981). The effect of an introductory course in microeconomics on the political orientation of students. The Journal of Economic Education, 12(2), 54-57.

Macve, R. (2014). "Trading Places" : A UK (and IFRS) comment. Accounting, Economics, and Law: A Convivium, 4(1), 27-40.

Malek, N. P., Hall, J. C., \& Hodges, C. D. (2016). The relationship between economics and ethics and the effectiveness of normative economics on student attitudes and learning. Journal of Economics and Economic Education Research, 17(1), 16-24.

Mankiw, G. (2017). Principles of economics (8th ed.). Boston, MA: Cengage Learning.

Mendelberg, T., McCabe, K. T., \& Thal, A. (2017). College socialization and the economic views of affluent Americans. American Journal of Political Science, 61(3), 606-623

Moore, K. B., Pack, S. J., \& Sabelhaus, J. (2016). Taxing income of top wealth holders. National Tax Journal, 69(4), 965-980.

Nasatir, D. (1968). A note on contextual effects and the political orientation of university students. American Sociological Review, 33(2), $210-219$.

National Taxpayer Advocate. (2010). 2010 Annual Report to Congress. Available at: https://www.irs.gov/advocate/national-taxpayeradvocates-2010-annual-report-to- congress

National Taxpayer Advocate. (2016). 2016 Annual Report to Congress. Available at: https://taxpayeradvocate.irs.gov/reports/2016-annualreport-to-congress/full-report

Needles, B. E., \& Powers, M. (2013). Principles of financial accounting. Financial accounting series (12th ed.). Cengage Learning

O'Brien, R. (2017). Redistribution and the new fiscal sociology: Race and the Progressivity of State and Local Taxes. American Journal of Sociology, 122(4), 1015-1049.

Piketty, T., \& Saez, E. (2007). How progressive is the U.S. federal tax system? A historical and international perspective. Journal of Economic Perspectives, 21(1), 3-24.

Riddle, T. (1978). Student opinions on economic issues: The effects of an introductory economics course. The Journal of Economic Education, 9(2), $111-114$.

Roberts, M. L., Hite, P. A., \& Bradley, C. F. (1994). Understanding attitudes toward progressive taxation. Public Opinion Quarterly, 58(2), 165-190.

Rose, P. I. (1963). The myth of unanimity: Student opinions on critical issues. Sociology of Education, 36(1), 129-149.

Sapirie, M. (2012). News analysis: Tax incentives for education: Not making the grade. Tax Notes, (October 22, 2012), 335-340.

Schreiber, S. P. (2015). New tax on expatriates' gifts and bequests gets prop. regs. Journal of Accountancy, 220(6), 75-76.

Scott, J. H., \& Rothman, M. P. (1975). The effect of an introductory economics course on student political attitudes. The Journal of Economic Education, 6(2), 107-112.

Selingo, J. (2015). Is college worth the cost? Many recent graduates don't think so. The Washington Post, Available at https://www.washingtonpost.com/news/grade-point/wp/2015/09/30/is-college-worth-the-cost-many-recent-graduates-dont-think-so/ ?utm_term=.1fa4dıfed 914 . 
Settlage, D. M., Settlage, L. A., \& Wollscheid, J. R. (2015). Measuring knowledge in principles of economics courses. Journal of Economics and Economic Education Research, 16(3), 241-252.

Shevlin, T. (2007). The future of tax research: From an accounting professor's perspective. The Journal of the American Taxation Association, 29(2), 87-93.

Slemrod, J. (1995). Professional opinions about tax policy: 1994 and 1934. National Tax Journal, 48(1), 121-147.

Slemrod, ]. (2006). The consequences of taxation. Social Philosophy and Policy, 23(2), 73-87.

Smith, A. (2010). The theory of moral sentiments. Penguin.

Smith, P. (2002). Complexity in retirement savings policy. National Tax Journal, 55(3), 539-553.

Stockwell, C. (2014). Same as it ever was: Top 10 mot popular college majors. USA Today. Available at: http://college.usatoday.com/2014/10/26/same-as-it-ever-was-top-10-most-popular-college-majors/

Tanzi, V. (2014). Taxation and equitable economic development: A historical note. Paper prepared for presentation at the Fedesarrollo and Woodrow Wilson Center' s Conference on “Hacia una Nueva Reforma Tributaria," Bogotá, Colombia, August 28, 2014.

Tetzlaff, R. (2016). Top 10 most popular majors in the U.S. College Factual. Available at: http://inside.collegefactual.com/stories/top-10-mostpopular-majors

Ubel, P. A. (2017). Why rich people hate taxes.Psychology Today. Available at: https://www.psychologytoday.com/blog/scientocracy/201709/whyrich-people-hate-taxes-its-not-reasons-you-think

Weakliem, D. L. (2002). The effects of education on political opinions: An international study. International Journal of Public Opinion Research, 14(2), 141-157.

Zeff, S. A. (2014). Some historical reflections on " Have academics and the standard setters traded places?" Accounting, Economics, and Law: A Convivium, 4(1), 41-48.

Zucman, G. (2015). The hidden wealth of nations: The scourge of tax havens. University of Chicago Press. 